\title{
Analysis of the Biomechanical Behavior of the Intervertebral Discs by Modeling Three-Phase Finite Elements
}

\author{
Filiz Karabudak ${ }^{1}$, Hamid Zamanlou ${ }^{2 *}$ \\ ${ }^{1}$ Gumushane University, Faculty of Engineering and Natural Science, Departmant of Mechanichal Engineering, Gumhushane, Turkey, (ORCID: 0000-0002-7365- \\ 0333), filizkarabudak@gumushane.edu.tr \\ 2* Ataturk University, Faculty of Engineering, Departmant of Mechanichal engineering, Erzurum, Turkey, (ORCID: 0000-0002-9780-8924), \\ zamanloohamid@gmail.com
}

(International Conference on Design, Research and Development- 15 - 18 Aralık 2021)

(DOI: 10.31590/ejosat.1039335)

ATIF/REFERENCE: Karabudak, F. \& Zamanlou, H. (2021). Analysis of the Biomechanical Behavior of the Intervertebral Discs by Modeling Three-Phase Finite Elements. European Journal of Science and Technology, (32), 702-704.

\begin{abstract}
Intervertebral discs act as a shock absorber to counteract the blows to the spine. These elements have the ability to deform when applied pressure, thus reducing the intensity of impacts. The main shape of discs is spherical when not under pressure; but when they are placed between the vertebrae, they expand under the pressure. One of the important functions of intervertebral discs is to facilitate movements in the spine

In order to study biological mechanics as one of the engineering infrastructures, in this paper, the combined modeling of finite element intervertebral discs as a saturated porous soft tissue is discussed. First, according to the continuum mechanics, the mathematical model is extracted and then the finite element model is prepared by ANSYS program package. Based on the different loads according to the available medical information, the biomechanical behavior of the disk was investigated. This model can be used to investigate the behavior of intervertebral discs in patients before or after surgery.

In this paper, in addition to the mathematical model, the mechanical behavior of the disk and the stress distribution under different loads were investigated.
\end{abstract}

Keywords: Intervertebral Discs, Finite Elements Methods, Stress Distribution

\section{Üç Fazlı Sonlu Elemanları Modelleyerek Omurlararası Disklerin Biyomekanik Davranışının Analizi}

$\ddot{\mathbf{O} z}$

Omurlararası diskler, omurgaya gelen darbelere karşı koymak için bir amortisör görevi görür. Bu elemanlar, basınç uygulandığında deforme olma yeteneğine sahiptir, böylece darbelerin yoğunluğunu azaltır. Disklerin ana şekli, basınç altında olmadığında küreseldir; ancak omurların arasına yerleştirildiklerinde basınç altında genişlerler. Omurlararası disklerin önemli işlevlerinden biri, omurgadaki hareketleri kolaylaştırmaktır.

Biyolojik mekaniği mühendislik altyapılarından biri olarak incelemek için, bu yazıda, doymuş gözenekli yumuşak doku olarak intervertebral disklerin birleşik modellemesi tartışılmaktadır. İlk olarak sürekli ortam mekaniğine göre matematiksel model çıkarılmış ve daha sonra ANSYS program paketi ile sonlu elemanlar modeli hazırlanmıştır. Mevcut tıbbi bilgilere göre farklı yüklere dayanarak diskin biyomekanik davranışı araştırıldı. Bu model, hastalarda ameliyattan önce veya sonra intervertebral disklerin davranışını araştırmak için kullanılabilir.

Bu yazıda, matematiksel modele ek olarak, diskin mekanik davranışı ve farklı yükler altındaki gerilme dağılımı incelenmiştir.

Anahtar Kelimeler: Omurlar Arası Diskler, Sonlu Elemanlar Yöntemi, Gerilme Dağılımı

*Corresponding Author: zamanloohamid@gmail.com 


\section{Introduction}

The bony parts of the spine are called the vertebrae. There are discs between the two vertebrae of the spine. The ligaments of the spine are also wrapped around the vertebrae and discs and protect them. The spine has seven vertebrae in the cervical region, 12 vertebrae in the middle part (thoracic spine) and 5 vertebrae in the lumbar region. Each intervertebral disc consists of two central and outer parts. The central part of the disc is made of a soft, jelly-like substance called nucleus pulpus, and the outer part, which surrounds the center of the disc, is a stronger tissue called the annulus fibrus.

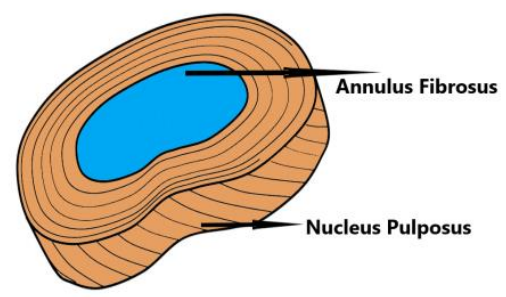

Figure 1. Intervertebral Disc

In general, the intervertebral disc is a hydrated soft tissue with a saturated porous structure that can be modeled in different ways (Suh \& DiSilvestro, 1999). In recent years, various researches have been done to model soft tissues as multiphase conditions. Most researchers have studied the nature of soft tissue from the perspective of two-phase composition (In two separate phases or as a prolastic phase) (Yang \& Smolinski, 2006). The three-phase theory of soft tissue modeling was first proposed in 1991 (Lai, Hou, \& Mow, 1991). Among the modeling, the pro-elastic model with displacement and inflation is considered as the most complete model.

In this paper, in addition to three-phase modeling, the biomechanical behaviors of the intervertebral disc by finite elements are investigated.

\section{Material and Method}

\subsection{Mathematical Modeling}

In this mathematical model, the intervertebral disc is considered as a three-phase environment :
1- Porous and solid permeable phase
2- Incompatible fluid phase
3- Electrochemical phase

The relationships governing the model are dynamically extracted using the laws of Continuum mechanics, the theory of porous media, and Darcy's law (Mathematical model for tissue engineered intervertebral disc as a saturated porous media).

In the saturated porous model section, considering the forces acting on the porous solid phase, the law of motion size conservation can be written in the absence of physical forces as follows:

$$
\frac{\sigma T_{j i}}{\sigma X_{j}}-\rho \ddot{\mathrm{u}}_{i}-n \rho_{f}\left(J^{-1} \frac{\sigma X_{l}}{\sigma X_{j}}\right) \ddot{\mathrm{w}}_{j}=0
$$

In relation (1) $\mathrm{u}$ is solid phase displacement; $\mathrm{w}$ is Relative displacement of the fluid phase, $\mathrm{n}$ is Porosity coefficient, $\mathrm{J}$ is Jacobin Matrix.

In the electrochemical model section, the governing relations of the model are obtained using the survival relations of motion size, equilibrium equations and electrochemical conditions (Sun, Gu, Guo, \& Lai, 1990).

$$
\nabla \cdot J^{+}-\nabla J^{-}=0
$$

The finite element formulation is performed using the Galerkin weight method (Gaudenzi \& Bathe, 1995).

$$
\begin{gathered}
{\left[\begin{array}{ccc}
M_{11} & M_{12} & 0 \\
M_{21} & M_{22} & 0 \\
0 & 0 & 0
\end{array}\right]\left[\begin{array}{c}
\ddot{\mathrm{u}} \\
\ddot{\mathrm{w}} \\
\dot{\mathrm{p}}
\end{array}\right]+\left[\begin{array}{ccc}
0 & 0 & 0 \\
0 & C_{22} & 0 \\
0 & 0 & 0
\end{array}\right]\left[\begin{array}{c}
\mathrm{u} \\
\dot{\mathrm{w}} \\
\dot{\mathrm{p}}
\end{array}\right]=\left[\begin{array}{l}
f_{1} \\
f_{2} \\
f_{3}
\end{array}\right]} \\
K^{+} \mu^{+}+k^{-} \mu^{-}=f_{4} \\
C \dot{\mathrm{c}}^{k}=f_{5}
\end{gathered}
$$

\subsubsection{ANSYS Model}

Finite element analysis offers researchers the opportunity to repeat the analysis by changing the model parameters. In this way, researchers can examine the effect of the relevant parameter on the whole model. on this occasion, more practical ways are obtained for surgery or treatments.

In this study, a three-dimensional model containing the details based on the geometry of real anatomical mesurment was prepared with the ANSYS package program. The finite elements Model is.4281 3D 8 nodes elements used for nucleus pulposus and 4197 3D 8 Nodes for annulus fibrosus. Length from anterior to posterior is $37 \mathrm{~mm}$, the distance from medial to lateral is about $24 \mathrm{~mm}$. FEM of intervertebral disc Shown in figure 2 .

Body heat was considered as the base and in addition to internal forces, external forces were applied. Materials Properties given in table 1 .

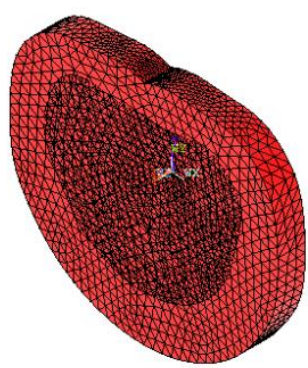

Figure 2. FEM of Intervertebral Disc 
Table 1. Materials Properties

\begin{tabular}{llll}
\hline $\begin{array}{l}\text { Material } \\
\text { parameters }\end{array}$ & Nucleus & Annulus & References \\
\hline $\begin{array}{l}\text { Young's } \\
\text { modulus }\end{array}$ & $0.15 \mathrm{MPa}$ & $1.5 \mathrm{MPa}$ & $\begin{array}{l}\text { (Houben, Drost, } \\
\text { Huyghe, Janssen, \& } \\
\text { Huson, 1997) }\end{array}$ \\
\hline $\begin{array}{l}\text { Extrafibrillar } \\
\text { fluid fraction }\end{array}$ & $70 \%$ & $60 \%$ & $\begin{array}{l}\text { (Urban \& } \\
\text { Maroudas, 1981) }\end{array}$ \\
\hline $\begin{array}{l}\text { Fixed charge } \\
\text { density }\end{array}$ & $0.24 \mathrm{mEq} / \mathrm{ml}$ & $0.18 \mathrm{mEq} / \mathrm{m}$ & $\begin{array}{l}\text { (Urban \& } \\
\text { Maroudas, 1981) }\end{array}$ \\
\hline Poisson ratio & - & 1 & $\begin{array}{l}\text { (Ferguson \& } \\
\text { Steffen, 2005) }\end{array}$ \\
\hline
\end{tabular}

\section{Results and Discussion}

In the finite element analysis, first, the material properties are defined. The nonlinear properties of the materials were also defined as bilinear. The bottom surface of model was protected against any motion as All DOF and loads applyed from the top surface. Figure 3 ilusterated the stress distribution on the disc.

Annulus Fibrosus and Nucleus Pulposus contact points have higher value of stresses. Damage can be predicted by 2 . Principal stresses. Figure 4 shows elastic strain

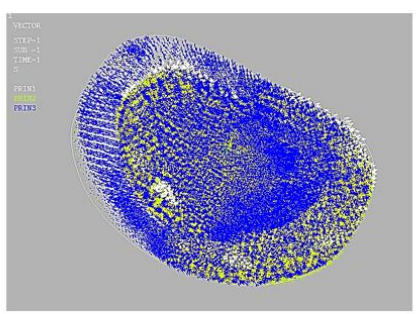

a)

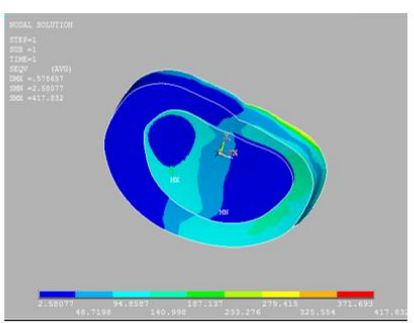

c)

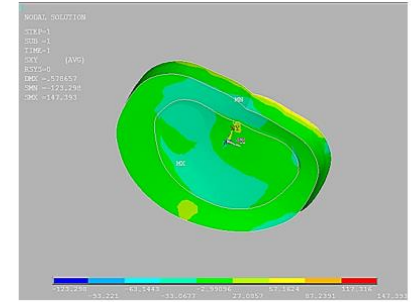

b)

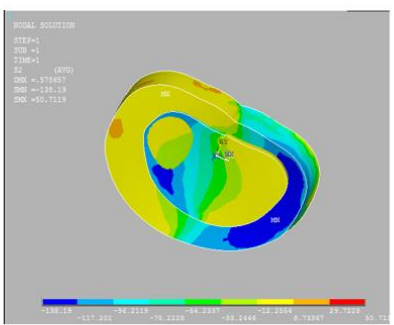

d)
Figure 3. a) Vectoral Stress distribution, b) xy Shear stress, c) VonMises Stress, d) 2. Principal Stress

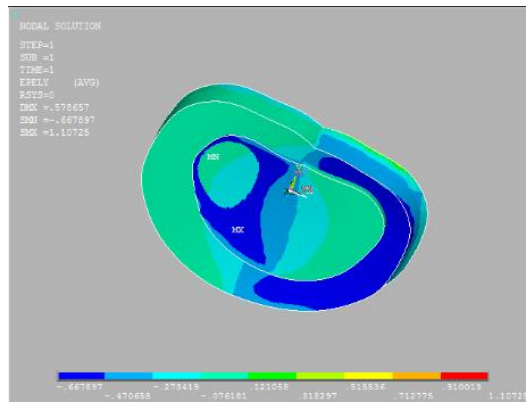

Figure 4. Elastic Strain

\section{Conclusions and Recommendations}

Prolastic three-phase finite element modeling can be useful as a basic model in investigating the effects of various parameters on disk biomechanical behavior. In this study, in addition to mathematical modeling, the disk finite element model was investigated to investigate stress accumulation.

Modeling of intervertebral discs in different states (healthy, damaged) will show their behavior in different systems.

Future work can predict disc dynamical behavior. And this study can be a guide for artificial discs.

\section{References}

Suh, J. K., \& DiSilvestro, M. R. (1999). Biphasic poroviscoelastic behavior of hydrated biological soft tissue. Journal of Applied Mechanics, 66(2), 528-535.

Yang, Z., \& Smolinski, P. (2006). Dynamic finite element modeling of poroviscoelastic soft tissue. Computer Methods in Biomechanics and Biomedical Engineering, 9(1), 7-16.

Lai, W. M., Hou, J. S., \& Mow, V. C. (1991). A triphasic theory for the swelling and deformation behaviors of articular cartilage.

Nikkhoo, M., Haghpanahi, M., Peirovi, H. A. B. I. B. A. L. L. A. H., \& Ghanavi, J. E. (2007). Mathematical model for tissue engineered intervertebral disc as a saturated porous media. In Proceedings of the 3rd International Conference on Applied and Theoretical Mechanics (pp. 197-201).

Sun, D. N., Gu, W. Y., Guo, X. E., Lai, W. M., \& Mow, V. C. (1999). A mixed finite element formulation of triphasic mechano-electrochemical theory for charged, hydrated biological soft tissues. International Journal for Numerical Methods in Engineering, 45(10), 1375-1402.

Gaudenzi, P., \& Bathe, K. J. (1995). An iterative finite element procedure for the analysis of piezoelectric continua. Journal of Intelligent Material Systems and Structures, 6(2), 266273.

Houben, G. B., Drost, M. R., Huyghe, J. M., Janssen, J. D., \& Huson, A. (1997). Nonhomogeneous permeability of canine anulus fibrosus. Spine, 22(1), 7-16.

Urban, J. P. G., \& Maroudas, A. (1981). Swelling of the intervertebral disc in vitro. Connective tissue research, 9(1), 1-10.

Ferguson, S. J., \& Steffen, T. (2005). Biomechanics of the aging spine. The aging spine, 15-21.

Stadelmann, M. A., Stocker, R., Maquer, G., Hoppe, S., Vermathen, P., Alkalay, R. N., \& Zysset, P. K. (2020). Finite element models can reproduce the effect of nucleotomy on the multi-axial compliance of human intervertebral discs. Computer methods in biomechanics and biomedical engineering, 23(13), 934-944. 